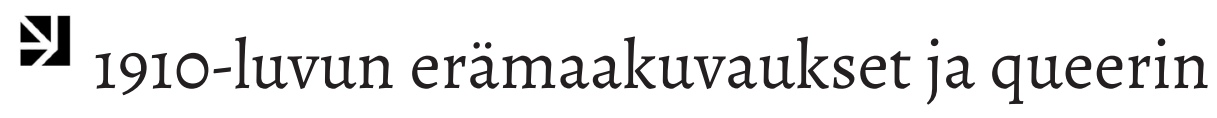
tehtävä

Elsi Hyttinen 
uomalainen kirjallisuus tuntee useita kahtiajakoja, joissa terve S kansalaisuus piirtyy esiin suhteessa ulkopuoleensa, siihen mitä se ei ole. Maaseudun ja kaupungin vastakkainasettelussa maaseutu on usein määrittynyt terveen subjektin luonnolliseksi ympäristöksi, kun taas kaupunki on degeneraation, seksuaalisuuden ja juurettomuuden alue (Karkama 1998, 19-22). Tai degeneroituneita, kieroon kasvaneita saattavat olla vain urbaanin sivistyneistön edustajat, ja heistä erotuksena toivo pannaan nuoriin, terveisiin työläisiin (Hyttinen 2014, 23-26). Koska kansakuntaisuudessa on kyse myös seksuaalisuuden organisoinnista, siinä mikä suljetaan ulos on usein queereja piirteitä: liiallista seksuaalisuutta, vääränlaista seksuaalisuutta, vääränlaisia tapoja elää sukupuolittuneessa maailmassa, kaikenlaista perverssiä sotkua. Mutta näissä jaoissa on kyse järjestäytyneen yhteiskunnan sisäisistä rajoista ja hierarkioista. Kuinka tähän polarisointien historiaan asettuu metsä? Asettuuko se?

Tämän kysyminen tuntuu yhä tärkeämmältä juuri nyt, vuosina joina keskilämpötilat pysyttelevät reilusti tavanomaisen yläpuolella. Ekokatastrofi vaatii miettimään luontosuhdettamme uudestaan. Tämän pohdinnan alueita taiteentutkimuksessa ovat erityisesti posthumanismi ja ekokritiikki, mutta osittain näiden teoriakenttien aiheuttamassa paineessa myös muut kriittisen ajattelun alueet miettivät uudestaan käsityksiään ihmisestä ja etenkin siitä, mitä kohta ei enää ole, luonnontilaisesta ympäristöstä. Tätä painetta tuntuu kanavoivan esimerkiksi queer-teoreetikko Jack Halberstam muotoillessaan tuoreessa kirjassaan seuraavaa ajatusta: "Queerness without wildness is just white homosexual desire out of the closet and in sync with a new normal": queer, joka mä̈rittyy ilman suhdetta villiyteen, on vain kaapin hylännyttä, uuteen normaaliin täydellisesti istuvaa valkoista homoseksuaalista halua (Halberstam 2020, 64, suom. EH). Artikkelini on yritys vastata tähän huutoon, tai reagoida siihen muutokseen, joka Halberstamin julistuksessa saa yhden muotoilun. Artikkelini on kirjallisuuden queer-näkökulmaista tutkimusta, mutta katseeni ei tavoittele tunnistettavaa homohalua, vaan tutkii villin ja ei-villin rajoja ja sitä, mitä aineistossani millekin puolelle asetetaan, ja mikä tämän erottelun funktio 1910-luvun kirjallisuudessa on.

Metsän ja queerin suhteen kysymiselle minulla on myös henkilökohtaiset syyni. Olen kirjoittamassa kirjaa 1910-luvun kirjallisuudesta ja queerista. Tuolla vuosikymmenellä kirjoitetaan paljon metsistä, myös koskemattomista erämetsistä. Silloin niitä vielä oli, ja toisaalta ideologinen paine korostaa metsien villiyttä ja koskemattomuutta oli suuri. Aineistostani alkoivat lähes omalla voimallaan erottua omaksi joukokseen kertomukset ekspansiivisesta suomalaisuudesta Lapin erämetsien reunoilla ja tätä kansallisen järjestyksen ulkolaitaa uhkaavasta ulkopuolisen figuurista. Tämä figuuri alkoi kiinnostaa minua, queeristi. Oli selvää, että se edusti metonyymisesti villiä luontoa, jonka kansakunta halusi pitää pihapiiriensä ulkopuolella. Mutta jostain syystä tämän luontoa personoivan hahmon olemassaolo tuntui uhkaavan myös kansakunnan 
seksuaalista järjestystä. Ulkopuolinen uhkasi yhtä aikaa normaalia, se uhkasi sosiaalista järjestystä, se uhkasi heteroseksuaalista onnea, ja se uhkasi lasta. Tämä artikkeli on yritys selvittää, mistä tässä järjestyksen ja ei-järjestyksen metsäisessä näyttämöllistämisessä oikein on kyse.

Aineistokseni valitsin kolme kaunokirjallista teosta, H. Ahtelan kertomuksen Pyhitysvaaran vanha asujain (1918) ja Väinö Katajan kaksi romaania, Noidan kirot (1914) ja Tuskaa (1907). Nämä Lappiin sijoittuvat romaanit eivät ole kirjallisuutemme merkkiteoksia, eivät edes Lapin-kuvauksen saralla. Tuoreessa vanhempaa Lapin kirjallisuutta (1901-1963) kartoittavassa teoksessaan Veli-Pekka Lehtola jättää molemmat kirjailijat lähinnä maininnalle. Hän toteaa Katajasta, että "Katajan teoksissa on myös puhtaasti viihteellisiä aineksia - piirre, joka teki hänestä monen kansankirjailijan tavoin suositun ja luetun". H. Ahtelalla oli hänelläkin taipumusta ennen kaikkea viihteellisen kirjallisuuden suuntaan: "Yhtä sekava kuin hänen kuvataiteellinen profiilinsa oli hänen kaunokirjallinen uransa, esimerkiksi fantasioivien eläintarinoiden kokoelma [--] ja kauhukertomusten kokoelma [--]" (Lehtola 2020, 24-26). Tutkimani teokset ovat viihteellisiä mutta lukijoiden keskuudessa suosittuja erämaan laidan kuvauksia, jotka on kirjoitettu vuosikymmenellä, jolloin kansalaisuuden rajoista käytiin kiihkeää implisiittistä ja eksplisiittistä neuvottelua. Vuoden 1906 parlamenttiuudistus oli tehnyt miltei kaikista suomalaisista kansalaisia, äänestäviä valtiollisia toimijoita. Yksi vuosikymmenen suurista kysymyksistä oli, millainen oli se joukko, jota kansalaiset edustivat. Millaiset olivat kansakuntaisuuden säännöt?

Näiden romaanien tapahtumapaikka on toisaalla, jossakin sivistyksen reunamilla. Olen hiljattain kirjoittanut toisenlaisestakin toisaalla-tilasta, saman aikakauden junapummikertomusten Amerikasta. Suhteessa queeriin nämä kertomukset ovat lähes peilikuvia. Kun kertomukset junapummeista ovat kuvauksia porvarillisesta perheestä kieltäytymisestä, ja junissa avautuva tila mahdollistaa miestenvälisen halun olemassaolon edes hetkellisesti, liikkeessä, vailla päätepistettä tai lunastusta (Hyttinen 2020), Lapin erämaiden rajoille sijoittuvissa tarinoissa kyse on sosiaalisen järjestyksen asettamisesta. Hobot junailivat pois kaikenlaisesta nationalistisesta kunnon kansalaisuudesta; tämän artikkelin aineistossa taas kansakunta nimenomaan rakentaa itseään. Veli-Pekka Lehtola onkin esittänyt, että Lapin kirjallisuus edustaa omalla tavallaan uudisasukaskirjallisuutta, jonka keskeinen juonne on villin luonnon alistaminen ihmisen palvelukseen. Tällaisen kirjallisuuden mielenmaisema on aivan toisenlainen kuin siirtolaiskirjallisuuden, joka käsittelee "alistettuun asemaan joutuneen vähemmistön pyrkimystä koota rikkinäinen identiteettinsä". (Lehtola 1997, 26.) Lapin kirjallisuutta hallitsee valloittajan näkökulma (mts. 61).

Romaanien kuvaamana aikana metsien käyttö oli nopeasti tehostumassa. Vielä 1800-luvun puolivälin Suomessa kotitaloudet olivat käyttäneet lähes kaiken maassamme kaadetun raakapuun, 1900-luvulle tultaessa teollisuus, vienti ja liikenne käyttivät raakapuusta jo puolet. Tämä synnytti jännitteitä kulttuurisen itseymmärryksen alueelle. Yhteiskunnan modernisaatio vyörytti 
teollisuutta eteenpäin ja loi vaurautta, toisaalta nouseva kansallistunto kiinnitti suomalaisuuden kuvaston juuri metsiin, etenkin koskemattomiin ikimetsiin. (Kuisma 2006, 452-455.) Käsittelemäni romaanit toimivat tällä kentällä etsien konfliktiin jonkinlaista symbolista ratkaisua. Markku Kuisma puhuu "vanhan uudisraivaajamentaliteetin, nationalismin ja teollisen edistysuskon" sulautumisesta uudeksi, kansakuntakehitystä ohjaavaksi kansakuntauskonnoksi (mts. 455), ja juuri tällaista sulatustyötä näen tutkimieni romaanien tekevän. Uusi kansalaisuskonto ei Kuisman mukaan hävittänyt eri juonteidensa väliltä poliittisia tai ideologisia eroja: niitä yhdistävä liima oli kuitenkin suhde luontoon alistettavana resurssina. (Mts. 452-456.)

Vaikka tässä tutkimani romaanit sijoittuvat erämetsien rajoille, ne eivät ole varsinaista eräkirjallisuutta, sikäli kun eräkirjallisuuden genreä määrittävä juonenkulku on yleensä irrottautuminen yhteisöstä, vaeltelu luonnossa, kahvittelu ja paluu kotiin (Varis 2003, 353). Kaikissa näissä romaaneissa on ikään kuin upotettuna myös tällaisia juonijaksoja, mutta niissä tapahtuu muutakin. Eräkirjallisuus valtavirtaistui vasta 1920-30-luvuilla, kun se metsän haltuunotto, jota aineistossani kuvataan, oli edennyt jo pitemmälle, ja villi luonto alkoi herättää nostalgiaa. Yhteistä eräkirjallisuuden kanssa näillä romaaneilla on kuitenkin ideologisten sitoumusten taso. Niin kuin eräkirjallisuuttakin, tässä artikkelissa lukemiani rajaseutujen kuvauksia luonnehtii ajatus luonnosta vihollisena, joka on voitettava ja alistettava (mts. 370-371) - tai joka H. Ahtelan tapauksessa alistuu taistelutta. Kansakuntaisuuden asettamisen kannalta on oleellista, että näissä romaaneissa kaikki kansallisen kulttuurin ulkopuoli merkityksellistyy villiyden alueeksi. Kansakuntaisuus on järjestystä, muu ei-järjestystä. Metsät ovat siis koskemattomia, vaikka niissä olisi esimerkiksi saamelaisasutusta: kansallinen katse liudentaa saamelaisuuden osaksi sitä koskematonta luontoa, jota sivistys on nyt ottamassa haltuun.

Veli-Pekka Lehtola (1997, 117) esitti jo väitöskirjassaan, että 1920- ja 1930luvun kirjallisuuden Lapin-kuvauksissa korostuu itseriittoinen maskuliinisuus. Tämän artikkelin aineistossa maskuliinisuus tuntuu organisoituvan toisin, ja oletan, että tämä liittyy ainakin osittain kolonialistisen projektin vaiheeseen. Artikkelini 1910-luvun pyörteissä kirjoitetussa aineistossa korostuu kansakuntaisuuden konstruointi individualististen sankareiden kuvaamisen sijaan. Individualistinen maskuliinisuus tuntuu liittyvän pikemminkin siihen, mikä uhkaa romaaneissani kaiken hyvän ja yhteisöllisen toteutumista: hahmoihin, joiden alistaminen tai voittaminen on tarinoiden keskeinen juonne.

Pohjoisamerikkalaisen queer-tutkijan Lauren Berlantin mukaan kansalaisuuden ajatukseen ikään kuin luonnostaan liittyy oletus tietynlaisesta seksuaalisuudesta. Berlant kutsuu tätä kansalliseksi heteroseksuaalisuudeksi, ja se kytkeytyy moniin kansalaisuuden jäsentämisen mekanismeihin, ei pelkästään makuukamarin alueelle. Koko kansakuntaisuus rakentuu heteroseksuaalisen intiimin ympärille ja suojaksi. Se olettaa kaiken toiminnan ytimeen yksityisen alueen, puhtaan seksuaalisuuden, joka on kaiken politiikan ja representaation 
ulkopuolella mutta perustelee niitä (Berlant 1997, 15-23). Jotta heteroseksuaalisuus voisi näyttäytyä luonnollisena, itsestään selvästi yhteiskuntajärjestystä perustelevana ytimenä, sen on suljettava jatkuvasti toisia vaihtoehtoja pois. Paitsi luontosuhteen kuvaamisesta, näissä Lapin-kertomuksissa on kyse myös juuri tällaisesta ulos sulkemisesta, joka on yhtä aikaa spektaakkeli ja kieltää kaiken spektaakkelimaisuutensa. Niissä on kaikissa hahmo, joka edustaa sitä, mitä romaaneiden keskiössä oleva yhteisö ei ole. Hahmolla voi olla eri kasvot: H. Ahtelalla se on peikko, Katajan Noidan kiroissa noita ja Tuskaa-romaanissa outo hiihtelijä, mutta hahmon tehtävä romaaneissa konstruoiduissa maailmoissa on sama. Vaikka figuurilla on eri teoksissa eri kasvot, sen rakenteellinen funktio ei muutu: kyse on hahmoista, jotka figuroivat sosiaalisen järjestyksen ulkopuolta, ja jotka siinä mielessä kuuluvat queerin alueelle (ks. Edelman 2004, 9, 27).

Queerin ymmärtäminen näin sitoo artikkelini queer-tutkimuskentän sisällä antisosiaalisen paradigmaan (ks. Caserio ym. 2006). Tässä paradigmassa queer ymmärretään kaiken ajateltavissa olevan sosiaalisen järjestyksen ulkopuoleksi. Lee Edelmanin sanoin: "kuoleman vietti on nimi sille, mitä queer sosiaalisessa järjestyksessä figuroi: kaikkien sosiaalisen elinkelpoisuuden muotojen negaatiota."' (Edelman 2004, 9, suom. EH) Tämä on hyvin erilainen tapa määrittää queer kuin se, jossa termillä viitataan ei-heteronormatiivisiin seksuaalisuuksiin ja identiteetteihin eräänlaisena sateenvarjokäsitteenä. Tarkastelemieni ulkopuolisuuden figuurien kutsuminen queereiksi ei siis tarkoita, että lukisin niitä esimerkiksi allegorioina homoseksuaalien asemasta 1900-luvun alun Suomessa. Sen sijaan väitän, että hahmot ja niiden kieltäminen tarvitaan, jotta kansakuntaisuus ja heteroseksuaalisuus on mahdollista esittää väistämättöminä.

Juuri antisosiaalisessa mielessä tutkimani kirjallisuuden peikossa, noidassa ja oudossa hiihtäjässä on kyse queerin figuurista. Ne ovat ulkopuolisuuden torjuttava kuva. Hahmot sinänsä ovat kerrotun maailman sisällä ja siten ajateltavissa olevia. Ne kuitenkin figuroivat sitä, mikä ei ole: sitä ulkopuolta, jota järjestys ei halua myöntää itsellään olevankaan. Metsä ja siihen metonyymisesti kytkeytyvät ulkopuolisen hahmot ovat toisaalla, se epäjärjestys, jota vasten järjestys piirtyy (Harrison 1992; Lehtonen 2008; Vadén 2010), mutta joka toisaalta jatkuvasti jää myös tuon järjestyksen tavoittamattomiin ja siksi uhkaa sitä.

\section{Alistuva luonto}

H. Ahtelan kertomuksessa Pyhitysvaaran vanha asujain peikko ja vanhat metsät ovat oikeastaan sama asia, niin tiukka on niiden kytkös toisiinsa. Kertoja, metsänhoitaja, kertoo Sirkku-nimiselle lapselle ensikohtaamisestaan peikon kanssa. Hän näkee peikon metsän laidassa, vaaran laella: 
- Eikö siellä metsiä hakattu? kysyy Sirkku (sillä minä olen metsämiehiä).

- Ei, ei hakattu, sillä siellä kasvaa vain kuusia, ja kuusia ei ennen hakattu.

Niitä ei kukaan tarvinnut. Erämaat samottiin läpi, suuret petäjät noukittiin sieltä pois, ja vedätettiin jokirantaan ja uitettiin alas jokisuulle, vaan kuuset saivat jäädä sijoilleen. Mutta nyt alettiin tarvita kuusia, ja minä olinkin lähtenyt Rusamoon juuri kuusten noutoon. Olin jättänyt miehet vaaran alle ja lähdin yksin laelle katsomaan näköalaa. Silloin sen näin - peikon. (Pyhitysvaaran vanha asujain, 9; tästä eteenpäin PVA)

Kertoja selittää suluissa olevansa metsämiehiä. Tämä ei ole mikään yleisnimi, vaan viittaa aivan tiettyyn yhteiskunnalliseen asemaan ja koulutukseen. Suomalaisia metsänhoitajia tutkineen Leena Paaskosken mukaan metsämiehiksi (forstmaneiksi) kutsuttiin vuosisadan vaihteen tietämissä Evon metsänhoitoopistosta valmistuneita metsänhoitajia (Paaskoski 2008, 9). Metsänhoitajat olivat virkamiehiä, joiden ilmaantuminen paikalle merkitsi metsän luonnontilaisuuden päättymistä: metsänhoitajalla oli valta päättää, mitkä puut kaadettiin ja mitkä jäivät seisomaan. Metsänhoitajan hahmoon kiinnittyy paljon myös herravihaa. Metsänhoitajia suomalaisessa kirjallisuudessa tutkinut Hannes Sihvo $(2002,226)$ toteaa, että ainakin Ilmari Kiannon kuvaamana metsänhoitajan "voi virkaherrana rinnastaa minkä hyvänsä pitäjän vallesmanniin ja kirkkoherraan". Metsänhoitaja oli ulkopuolinen ja koulusivistystä saanut herra, joka tuli kansan tapoja sotkemaan ja mestaroimaan. Tässä Ahtelan kertomuksessa ei kuitenkaan vihamielisyydestä ole häivääkään. Vaikka metsurijoukot jo odottavat käskyjään vaaran alla, peikko näyttäytyy "metsämiehelle" vapaaehtoisesti. Peikko on omankin käsityksensä mukaan menneen maailman hahmo. Katoava metsä ja peikon hahmo sulautuvat yhteen. Peikko on se koskematon metsä, jonka on väistyttävä erämaihin kurottautuvan kansakunnan tieltä. Myöhemmin romaanissa peikko muistelee, kuinka ennen oli toisin. Erämaissa kulki vain muutamia miehiä, eivätkä he yrittäneet puuttua luonnon kulkuun. Ottivat vain omansa metsästäen tai kalastaen, luontoa häiritsemättä. "Ei ole ollut riitaa meidän välillämme, sanoi Peikko. Kun ollaan miesten miehiä, ei tule riitaa." (PVA, 70)

Peikon repliikissä kiinnittää huomiota kolme tämän artikkelin kannalta kiinnostavaa seikkaa. Ensinnäkin, peikon ja ihmisten välillä ei aiemmin ollut riitaa. Peikko edustaa sitä luontoa, jota ihminen ei pyrkinyt ottamaan haltuun tai muokkaamaan. Toiseksi, peikko kiinnittyy erityiseen maskuliiniseen järjestykseen: hän on osa miesten miesten ketjua. Ja kolmanneksi, repliikki on imperfektissä. Tämän maailman on väistyttävä. Peikon repliikki kertoo ajasta, joka oli muttei ole enää.

Peikko kuuluu maailmaan, jossa ollaan miesten miehiä. Sosiaaliset suhteet rakentuvat yksittäisten miesten välille, eikä tuossa maailmassa ole naisia, ei parisuhteita eikä lapsia. Koteja ei perusteta eikä omaisuutta kerrytetä. 
Sitten Suuren Eränkävijän ajan ei Pyhitysvaaran Peikko ollut tavannut sellaista metsäntuntijaa kuin Lavelan Matti. Hän oli ihastunut tämän tulosta Isoon Rusamoon, hän oli monta kertaa ollut hänen kanssaan puheissa. Olipa hän monta kertaa aikonut ajattaa erääkin Matin tielle, mutta se oli tarpeetonta. Sillä Matti sai helposti tarvitsemansa, ja ylenmääräisiä pyyteitä ei hänellä ollut. Sai siellä olla riistaa, lähettyvilläkin, rauhassa, jos Matilla oli tarpeensa. (PVA, 50)

Miesten miesten maailmassa elämästä ei jää jälkeä luontoon eikä elämä suuntaudu tulevaan. Miehet vain ovat, kunnes jonain päivänä eivät enää ole. Nämä miehet ovat miltei täydellinen, joskin hiljainen ja kapinoimaton vastakuva sille, mitä Lee Edelman kutsuu reproduktiiviseksi futurismiksi. Reproduktiivinen futurismi viittaa kaiken politiikan organisoitumiseen tulevaisuutta figuroivan lapsen ympärille. Heteroseksuaalisuus, kansakuntaisuus, kaikki sosiaalisen olemisemme instituutiot perustelevat olemassaolonsa lapsen parhaalla tai tulevaisuudella, jota on rakennettava ikään kuin lasta varten (Edelman 2004, 2-3). Lapsen hahmoa kehystävä sosiaalinen järjestys tarjoutuu itsestään selvänä, se on järjestys joka ei myönnä itsellään olevan minkäänlaista ulkopuolta tai vaihtoehtoa. Queer on tämän järjestyksen kielletty negaatio. Se on siis paitsi jotakin muuta kuin tämä järjestys ja siinä mielessä sen negaatio, myös jotakin, jonka olemassaolo kielletään. Eihän reproduktiivisella futurismilla voi olla ulkopuolta, sillä kuka asettuisi vastustamaan sitä, että syntyy uusia tulevaisuuksia, että kansakunta lisääntyy, että vaurautta rakennetaan? Ei kai kukaan. Paitsi ehkä peikko.

Voisi luulla, että peikko suhtautuisi yksinäisten miesten maailmaan nostalgisesti, vaan ei. Hän on aivan valmis väistämään vaaran juurella odottavien tukkimiesten tieltä, koska elämä joukoissa on parempaa kuin yksin. Tässä Ahtelan kummallisessa, konfliktittomassa saagassa edes peikko ei halua kuulua peikkojen sosiaaliseen järjestykseen.

- Olen ollut yksin, sanoi peikko. - Voi, kuinka olisin ollut iloinen, jos meitä olisi ollut paljon. Ei ole koskaan liikaa. Kun on ollut yksin ymmärtää, ettei koskaan ole liikaa.

- Mikä sen nimi oli? kysyy Sirkku.

- Sillä ei ole nimeä, vastaan. - Se oli aina ollut yksin eikä sille kukaan ollut nimeä antanut.

- Eikö sillä ollut äitiä? kysyy Sirkku

- Ei, ei ollut äitiä ollut.

- Eikö sillä ollut isää?

- Ei, ei isääkään, eikä veljiä eikä sisaria.

- Voi peikko parkaa! sanoo Sirkku, ja äänessä värähtää tosi sääli. (PVA, 10-11) 
Peikko on täydellinen queerin figuuri, kaikkien sukulaisuussuhteiden ja sosiaalisen ulkopuolella. Hänellä ei ole edes nimeä, koska nimi edellyttäisi tilanteita, joissa tullaan puhutelluksi. Lukija voi halutessaan huokaista Sirkun mukana ja sääliä peikkoa. Niin itsestään selvää on tämän tarinan kehyksen sisällä se, että mitä tukkimiesten mukana on tulossa, on parempaa kuin miesten miesten yksinäisyys.

Minkä edestä peikon sitten on väistyttävä? Tämä tehdään hyvin selväksi teoksen lopussa. Muutoksen kuva ovat nuori mies, metsänhoitaja, ja nainen, jolle hän ei ole vielä kertomuksen viime sivuille mennessäkään "kerinnyt" tunnustaa rakkauttaan. Mutta kirjan viimeisellä aukeamalla tämä muuttuu:

- Nyt hän on kerinnyt, sanoo Peikko, ja nyt he tulevat käsityksin. Katso, nyt he tulevat tuolla. Mutta nyt tulee iso tuuli, nyt häviää Rusamo ja Pyhitys ja erämaat, ja minun täytyy lähteä.

Ja katso: nyt humisee koko luonto, kaikki heiluu ja pyörii ympäri. On kuin iso pilvi kohoaisi yli koko maan, kivinen harju alkaa täristä, ja kun Sirkku kääntää päätään, näkee hän, että juna tulla huristaa puuskuttaen savua ja höyryä yli sillan. Hän katsahtaa Peikkoon päin, mutta se oli jo lähtenyt. (PVA, 76)

Höyryjunana maisemaa tärisyttävä modernisaatio ja heteroseksuaalisuudelle perustuva kansakuntaisuus ovat ne voimat, jotka pyyhkivät yli erämaan kuin tuuli ja hävittävät sen, ja joiden edestä peikko väistää vastustelematta. Tarinassa ei ole ristiriitoja eikä tämä ole taistelu: kertomuksen maailmassa muutos on väistämätön. Kun suuret kuuset häviävät, katoaa peikkokin. Erämetsä on jotakin, jonka on lakattava olemasta, sillä nyt tulevaisuuteen kurkottava kansakunta tarvitsee jo kuusiakin. Vaikka peikosta aluksi kertoi minä-muodossa mies, metsänvartija, tässä lopussa miestä ja hänen rakastettuaan havainnoi Sirkku, alun kuuntelija. Pyhitysvaaran vanhan asujaimen vaihtoehdotonta muutosta todistaa lapsi, tulevaisuususkon kuva.

On kohosteista ja siksi merkillepantavaa, että Ahtelan ulkopuolinen on saanut juuri peikon muodon. Peikot ovat keskeinen hahmo skandinaavisessa folkloressa mutta myös kirjoitetussa kirjallisuudessa. Ruotsalainen kirjallisuudentutkija Yvonne Leffler on jäljittänyt tällaisen ulkopuolisen hahmon historiaa suhteessa goottilaiseen kauhuperinteeseen. Leffler puhuu goottilaisesta topologiasta (Leffler 2010,46), joka on skandinaavisessa kauhussa erilaista kuin keskieurooppalaisessa. Jos goottilaisuuden näyttämö Euroopassa oli linna tai sokkeloinen talo, pohjoisessa se on villi luonto. Usein henkilöhahmot ja ympäristö sulautuvat yhteen. Pelkäämme siis metsää, mutta käsittelemme pelkoa metsää metonyymisesti edustavan, siihen sulautuvan hahmon avulla. Lefflerin mukaan skandinaavinen kauhu rakentuu pelolle, ettei luonto olisi hallittavissa tai että 
pakanallinen menneisyys purkautuisi esiin (mts. 49). Mutta Ahtelan peikko ei ole lainkaan kauhistuttava. Tämä on osa romaanin merkitsevää kudosta: peikon ympäriltä puuttuva uhka alleviivaa kansallisen projektin oikeutusta. Junat ja ydinperheet saavat vallata entisen erämaan: peikko ymmärtää ja tekee tilaa. ${ }^{2}$

\section{Utuniemen kirous}

- Onko talo niemen nenässä ja näkyykö se järvelle? kysyi Selma.

- Ei näy tännepäin, sillä pitkin niemen rantaa kasvaa vankkaa koivikkoa, jota isävainaja ei raaskinut hakata... ja kielsi minuakin hakkaamasta...

Siitä pääsivät he keskustelun alkuun.

Simo kertoi, mitä hänellä oli mielessään. Hänellä oli jo hirret ajettuina uutta uhkeaa päärakennusta varten. Siitä tulisi niin korkea, että harja ja pääty näkyisivät tännekin päin järveä, vaikka rantakoivikon jättäisikin hakkaamatta. Hän kertoi maanviljelyksestään, karjastaan, metsän ja järven antimista, kuinka ne olivat runsaat... Yhdessä he tekisivät Utuniemestä hyvän talon, jossa eläisi rennosti...

- Kun ei tullut minulta siellä ennen käydyksi, vaikka usein teki mieleni, kun pyysit tulemaan, - sanoi Selma, itseään moittien.

- No nytpä tuon näet ja saat viipyä pitemmän aikaa, - naurahti Simo.

Ja samalla hän kiinnitti hihnaa ja kiirehti tottunutta ja vireää ajokastaan nopeampaan vauhtiin.

Aurinko oli jo noussut korkeammalle paistaen nyt yli koko suuren, saaririkkaan ja niemistään kuuluisan Raahonjärven ja valaisten ympäristöä. Joka haaralta näkyi tänne järven selälle asumatonta kiveliötä, korkeita, puuttomia vaarain lakia ja paljukoita, äärettömiä tummia metsiä ja kukkuloiden kupeilta harmahtavia hongikoita. Ei missään näkynyt asuttua maailmaa, ei ainoankaan niemen nenässä näkynyt ihmis-asuntoa eikä yhdenkään saaren rannassa venevalkamaa.

(Noidan kirot, 7; tästä eteenpäin NK)

Myös Väinö Katajan Noidan kirot -romaanissa vastakkain ovat ekspansiivinen suomalaisuus ja koskemattomat metsät. Kansakunta on tukevasti asettautunut jo yllä olevassa sitaatissa ylitetyn Raahonjärven etelälaidalle: siellä on poron kyydissä matkaavan Selman lapsuudenkoti. Kotona on karjaa, peltoa, rakennuksia, sisaruksia ja jonkinlaista työväkeäkin. Matkan päätepiste, poroa ohjastavan Simon koti taas on etäisyyksien tästä yhteisöllisyydestä erottama: edes Selma ei ole koskaan siellä käynyt. Matkalla talojen välillä näkyy tuntikausia vain koskemattomia metsiä, ei ihmisasutusta lainkaan. Itse Utuniemen talokin piilottautuu metsään, sillä Simon isä on kieltänyt rantakoivikon kaatamisen. Se, mitä tässä alun idyllissä ei vielä kerrota on, että Utuniemi on uskomusten mukaan kirottu. 


\section{Luontoa personoivan hahmon olemassaolo tuntui}

uhkaavan myös kansakunnan seksuaalista järjestystä.

Simon kotitilan mailla asui perintötiedon mukaan aikoinaan saamelainen noita Jantukka, jonka suomalaiset uudisasukkaat tappoivat. Ennen kuolemaansa Jantukka langetti mailleen kirouksen, joka on kohtaava kaikkia sinne asettuvia. Noidan hahmoon tuntuu kiinnittyvän paljon yhteisön tuntemaa syyllisyyttä saamelaisten kohtalosta. Tätä syyllisyyttä ei kuitenkaan myönnetä, ja ehkä siksi Jantukan kirous ei unohdu vaan vainoaa niemen asukkaita: uskoa Jantukan pahuuteen on uudistettava jatkuvasti, jotta hänen surmaamisensa pysyisi oikeutettuna tekona. Metsän kuvaamisen kannalta Jantukka on kiinnostava hahmo. Ensinnäkin hän edustaa toisenlaista luontosuhdetta kuin metsän raivaamiselle perustuva utuniemeläinen tilanpito. Kuten Ahtelan peikko, hän kuuluu maailmaan, jossa luontoa ei taivuteta ihmisen tahtoon vaan siltä otetaan tarvittava, häiritsemättä. Kirouksensa langettaessaan Jantukka kuitenkin sulautui ympäröiviin metsiin uudella tavalla. Myös hän on nyt yhtä metsän kanssa, muttei samanlaisella leppoisalla, metonyymisen konfliktittomalla tavalla kuin Ahtelan peikko. Jantukka on selitys sille, että metsä näännyttää raivaajansa, että se on arvaamaton ja hylkii asuttajiaan. Noidan kirot on huomattavasti eksplisiittisemmin goottilaisen kauhun jatkumolla kuin Ahtelan Pyhitysvaaran vanha asujain. Lefflerin (2010, 46-49) mukaanhan yksi pohjoismaisen kauhun erityispiirteistä on juuri pelko pakanallisen menneisyyden paluusta nykyhetkessä; toinen on luonnon hallitsemattomuuden herättämä pelko, jota usein käsitellään luontoon kiinteästi sulautuvan hahmon tai hahmojen avulla. Jantukka on pakanallisen menneisyyden hahmo, mutta pelottava juuri siksi, että hänen mahdollinen, todentamattomissa oleva läsnäolonsa merkitsee koko niemen, hän on kirouksensa myötä kaikkialla eikä tarkasti missään.

Teuvo Puro ohjasi romaanin pohjalta kauhuaineksia sisältävän mykkäelokuvan vuonna 1927. Romaanin ja elokuvan välillä on kiinnostavia eroja: Elokuva 
etualaistaa kauhun ja kertomuksen yliluonnolliset elementit, ja on siten puhtaammin kauhuviihdettä. Romaani taas on ambivalentimpi sen suhteen, onko mitään ulkopuolista noituutta lainkaan olemassa, vai onko noidan hahmo ja tarina kirouksesta vain yhteisön tapa nimetä niitä asioita, joita se ei pysty käsittelemään. Romaanissa noidan sinkoama kirous on jotakin, joka ennen kaikkea estää heteroseksuaalisen normaalin toteutumista: Simo ja Selma ovat onnettomia, heidän välilleen ei synny intiimiyttä eikä ympärilleen turvalliselta tuntuvaa kotia. Kodin ylläpitäminen metsän keskellä, kirousta peläten on hanke, joka uuvuttaa heidät molemmat.

Sekä romaanissa että elokuvassa on useita kohtauksia, joissa soudetaan Utuniemestä Selman kotitilalle järven toiseen päähän, tai takaisin. Järven etelälaidalla on puhdasta, hallittua, järjestäytynyttä ja varmaa. Pohjoisessa on Simon hiljainen, kirottu tila, jonka ainoa asukas nuoren parin lisäksi on Simon sokea sisar Elsa, joka tarinan aikana kuolee. Elokuva alleviivaa myös visuaalisesti sitä, kuinka sosiaalinen järjestys jatkuvasti epäonnistuu Utuniemessä. On paljon kuvia naisista luonnon ympäröiminä. Nämä kuvat eivät ole idyllisiä vaan naiset ovat kuin taipuneita toisiaan kohti, käsikkäin tai toisiinsa takertuneina keskellä autiutta, pahaa torjuen. Jo Elsan tervetulosuudelma Selmalle on hätääntynyt ja samalla haparoivan intohimoinen, kuin pelastajaa tervehtivä. Simo katsoo naisia pitkään ja kääntyy sitten pois, kuten monesti myöhemminkin.

Konkreettisen muodon paha saa rantametsiä kaatavista tukkilaisista, joiden kanssa Selma osuu samaan järvenpoukamaan, kun Simo on hakemassa lehmää Selman kotoa. Paksu-Sakariksi kutsuttu tukkilainen raiskaa Selman. Selma tulee raskaaksi ja synnyttää lapsen, jota Simo vuosia myöhemmin alkaa epäillä Sakarin siittämäksi. Simon ja lapsen kalaretkellä jotakin outoa tapahtuu, lapsi putoaa veneestä ja hukkuu. Elokuvassa Simo hyppää lapsen perään, kirjassa ei.

Vene kolahtaa tulvan tuomaan puuhun, heilahtaa. Aaprami keikahtaa selälleen veneen laidan yli. Pienet kädet vilahtavat apua anoen, Simo hyökkää pystyyn, mutta samalla hänen ruumiinsa ikään kuin halpaantuu. Uhmana vilahtaa hänen sielussaan: älä auta...

Simo istuu teljolla ja tuijottaa siihen paikkaan, johon Aaprami on pudonnut. Sitten kääntää hän verkalleen veneen takaisin päin ja alkaa soutaa. Verkkojaan hän ei muista... Ei ymmärrä mitä on tapahtunut. Pimeys laskeutuu sydämeen ja mieleen. (NK, 80-81)

Selma epäilee Simon tappaneen lapsen tahallaan, muttei puhu mitään. Molemmat tulkitsevat, että kaikki tapahtunut johtuu noidan kirouksesta. Simo hajottaa rannalta vanhan tulisijan, ainoan konkreettisen asian, joka on jäljellä Jantukan kodasta.

Selma tulee uudestaan raskaaksi ja lähtee äitinsä hoiviin järven toiseen päähän talveksi. Simolle aukeaa yllättäen tilaisuus tappaa vaimonsa raiskaaja, mutta viime hetkellä hän kääntyy pois. 
Hän rientää vaimonsa luo, joka on synnyttänyt. Elokuvassa lasta ei näytetä, mutta Selma kysyy, voitaisiinko tällekin antaa nimeksi Aaprami kuten kuolleelle esikoisellekin. Kamera seuraa tarkasti Simon kasvoja, kun ajatus ensin kauhistuttaa häntä. Lopulta Simo myöntyy: he voivat aloittaa alusta uuden lapsen kanssa. Kuten viimeinen tekstiplanssi elokuvassa kuuluu: "Nyt vasta on Utuniemi oma kotimme. En enää noidan kiroja pelkää." Kirjassa sen sijaan loppurepliikkiä edeltävä kohtaus rakentuu olennaisesti toisin.

- Täällä hän on, - kuiskaa Selma, varovasti nostaen peitettä kasvojen päältä. Simo kumartuu katsomaan. Lapsi nukkuu. Hän katselee hetken lasta ja silmää sitten Selmaan.

Nehän ovat aivan samanlaiset kasvot kuin Aapramivainajankin! Simo tarttuu Selman käteen.

- Selma! Selma!... Sillähän on Aapramivainajan kasvot!...

- Niin ne ovat, mutta silmät ovat aivan kuin sinun silmäsi, - sanoo Selma tyynin äänin ja liikkein.

Simo tuijottaa lapseen, kauhu kasvoillaan.

- Ja vartalo pitkä!... Katsos tänne!

Simo ei vain tahdo säikähdyksestään selvitä.

- Nyt olemme päässeet Jantukan kiroista! Nyt en enää usko enkä luule mitään! Yhtä kuitenkin pyytäisin: panemmeko hänen nimekseen Aaprami? Simo miettii hetken, pari kertaa nousee rinta raskaasti ja sieraimet levenevät. Mutta sitten silmää hän lapseen, joka on herännyt ja katselee sinisin silmin eteensä...

Simon rinta tyyntyy, kasvoille ilmestyy onnellinen hymy, kun hän Selman silmiin katsoen sanoo:

- Olkoon Aaprami.

Selma laskee kätensä Simon kuumalle otsalle ja kuiskaa:

- Nyt on Utuniemi oma kotomme! En enää noidan kiroja pelkää! (NK, 121-122)

Jos uusi lapsi on aivan saman näköinen kuin vanha, oliko vanhalla sittenkään eri isä? Tämä lopun kuva, jossa lapsi korvataan toisella ja heteroseksuaalinen onni on vihdoin mahdollinen menneisyyden vaiettua, on vähintäänkin jännitteinen. On epäselvää, oliko mitään torjuttavaa ulkopuolista koskaan olemassakaan, ja jos oli, on myös epäselvää, onko hänet nyt tuhottu. Utuniemen tila on edelleen mailla, joilta saamelaisasutus häädettiin, ja jonka tuhoaminen henkilöityi Jantukkaan. Simon isä tiesi, että Jantukka oli edelleen läsnä rantakoivikossa, jota ei saanut kaataa. Simo on sukupolvea kauempana siitä väkivallasta, joka aloitti suomalaisyhteisön levittäytymisen järven rannoille. Hän uskoo, että koivut voi kaataa, kiukaan hävittää ja siten päästä eroon kaikesta siitä käsittämättömästä, heteroseksuaalisen kansakuntaisuuden sääntöihin mahtumattomasta, jota Jantukan hahmo romaanin maailmassa personoi. 
Väinö Katajan Tuskaa-romaani on kiinnostava variaatio heteroseksuaalisuuden kansakuntaisuuden asettamisen draamasta, koska siinä ulkopuolinen, luontoon assosioituva paha ei ainoastaan uhkaa järjestystä vaan onnistuu, miltei, estämään sen toteutumisen. Se on kiinnostava variaatio myös siksi, että tämä pahan figuurin konkretisaatio ei ole metaforinen eikä mytologinen, vaan hänelle annetaan historia. Veli-Pekka Lehtola on kirjoittanut siitä, kuinka Lapin-kirjailijat Lappia kuvatessaan samalla rakensivat ja loivat lappilaista identiteettiä. Ei ollut mitään lappilaisuutta sinänsä, johon eri representaatiot palautuisivat, se oli olemassa vain "kertomuksina, tarinoina, historioina". (Lehtola 1997, 23.) Tuskaa-romaani tuntuu olevan tietoinen tällaisista kumuloituvista kulttuuristen kuvausten siteerauksista, koska se hyödyntää tämän artikkelin keskiössä olevaa ulkopuolisen hahmoa kurittomasti, yhtä aikaa oikein ja väärin.

"Kiveliön kävijäksi" kutsuttu hahmo on tullut etelästä ja asettunut Lappiin. Kiveliön kävijä ei siten olekaan autenttisesti ulkopuolinen, ei peikko eikä noita, vaan kansakunnan jäsen, jonka ulkopuolisuus on performatiivista ja seurausta kulttuurisessa käsikirjoituksessa tarjolla olevan toisen paikalle asettumisesta (performatiivisuudesta ks. esim. Butler 1999, xiv-xxvi). Toisin sanoen romaani tekee näkyväksi sen, kuinka ulkopuolisen, ulossuljettavan hahmon paikka on eräänlainen rakenteellinen välttämättömyys kertomukselle yhteisöstä. Paikka edeltää yksittäistä paikan haltuunottoa, ja siksi se mahdollistaa senkin, että paikalle asettuu vääränlainen hahmo. Jo hahmon nimi, tai pikemminkin nimettömyys, on osa tätä performanssia. Niin kuin peikko, myös Kiveliön kävijä merkityksellistyy suhteessa luonnonympäristöön. Tieteen termipankin mukaan kiveliö on erämaan synonyymi ja tarkoittaa laajaa asumatonta ja tietöntä maa-aluetta. Termipankki antaa myös englanninkielisen selitteen, joka kertoo suomenkielistä enemmän: "A large tract of primitive country with its land and waters, native plant and animal communities, substantially unmodified by humans and their works." (Tieteen termipankki 2020.) Kiveliön kävijän nimi viittaa siis eksplisiittisesti kulttuurin ulkopuolelle asettumiseen. Kiveliö on luonnontilaisia maita ja vesiä, kasveja ja eläimiä, joihin ihminen ei ole vaikuttanut.

Vaikka romaani yhtäältä purkaa näkyviin sitä, kuinka ulkopuolisuus on seurausta asettumisesta ulkopuolisen rakenteelliselle paikalle, se ei estä romaania toisaalta hyödyntämästä edeltä tuttua tapaa hälventää eroa ulkopuolisen hahmon ja villin luonnon väliltä. Myös Kiveliön kävijä sulautuu erämaahan. Häntä ei pakkanen häiritse eikä lumi, hän on osa maisemaa.

Synkän korven pimeässä istuu Kiveliön kävijä pakkasyössä puoleksi kinokseen uponneena. Häntä ei hätyyttele vilu eikä nälkä, eikä hän tuskaannu odotukseen, sillä hän on varma saaliistaan. Niin varma, että hän jo edeltäpäin tietää, kuinka hänen tekonsa käy ja miten hänen on meneteltävä. 
Hänen suuret tummat silmänsä säkenöivät, ja näyttää kuin uppoisi hänen teräksinen katseensa synkän kallion sisään. (Tuskaa, 82; tästä eteenpäin T)

Nimettömyys, näkymättömyys ja sulautuminen luonnonympäristöön ovat niitä aineksia, joista Kävijän kammottavuus rakentuu. Queer ulkopuolisuuden figuurina voi siis saada hahmon, jolla on nimettävissä olevia ominaisuuksia, mutta se ei tee queerista itsestään käsitettävää. Vaikka queerista hämärästä nousisi hahmoja osittaisen käsitettävyyden alueelle, queerin funktio ei tästä siirtymästä muutu. Queeriuden rakenteellinen paikka, ja tarve täyttää se aina jollakin, pysyvät. (Edelman 2004, 27.) Järjestys tarvitsee ulkopuolensa, vaikka juuri tämä piirre tekee järjestyksestä niin haavoittuvan. Vaikka Kiveliön kävijä kuolisi, yhteisö pelkäisi epäilemättä silti ulkopuolista pahaa, ja joku tuolle paikalle taas asettuisi.

Jälleen ekspansiivista suomalaisuutta edustaa etelästä tuleva metsänhoitaja, nyt Waltteri nimeltään. Heti tarinan alussa hän ihastuu saamelaiskodassa kohtaamaansa Eilaan. Kuten Ahtelan peikko, myös Eila on irti perheen ja sukulaisuuden kehyksistä. Hän on ollut kasvattina eri perheissä, joille Kiveliön kävijäksi kutsuttu mies on hänen ylöspidostaan maksanut. Kukaan ei oikein tiedä, onko Kiveliön kävijä hänen isänsä vai ei.

Waltteri ja Eila saavat lapsen ja aikovat naimisiin. Tätä ei Kävijä hyväksy, ja eräänä yönä hän rakentaa ansan ja saa Waltterin putoamaan reestä. Poro karkaa ja Waltteri jää yksin lumiseen tunturiin. Kun hänet monta päivää myöhemmin löydetään, on jo liian myöhäistä. Hän ei ole vielä kuollut, mutta niin sairas, ettei selviä romaanin loppuun saakka. Viimeisessä, melodramaattisessa luvussa tapahtuu kolme asiaa. Norjassa Eilan taustoja tutkimassa olleet miehet saavat selville, että Kiveliön kävijä on ryöstänyt hänet hänen oikeilta vanhemmiltaan; Waltteri kuolee; ja Eila luopuu koston aikeista.

- Kaikesta näistä päättäen, - sanoo nimismies, katsellessaan papereita ja todisteita, jotka Jaakko on tuonut matkassaan, täytyy Eilan olla pastori Håkansenin tytär, joka vuoden vanhana vietiin venheestä ja katosi tietämättömiin... Tässä on kastetodistus... Ingrid Sofia. Mutta mikä on sitten se, jota Kiveliön kävijäksi nimitetään?

- En minä hänestä tarkemmin tiedä, eikä sitä kukaan ole kysynyt, kun kaikki ovat enimmäkseen häntä peljänneet eivätkä mitään ole uskaltaneet urkkia... Ja kun on kaikille rauhan antanut ja ahmoja ahdistellut, niin ei ole sen enempää välitetty, - selittää Jaakko tietojaan nimismiehelle.

- Onko hänessä koskaan ollut huomattavissa mielipuolen oireita? tiedustaa lääkäri.

- Minä en ole koskaan saanut selvää, onko hullu vai viisas, mutta paremmin minusta on hullu...

- Kamala, hirveä mies hän mahtaa olla! (T, 107-108) 
Kiveliön kävijä onkin siis lapsenryöstäjä, ja Eila se lapsi, jota vastaan on rikottu. Kiinnostavaa on, ettei koko romaani selitä sanallakaan, miksi Kävijä on lapsen oikeilta vanhemmiltaan ryöstänyt. Hänhän maksaa lapsen hoitamisesta muille, eikä siis käytä tätä millään lailla hyväksi, edes työvoimana kotona - ja ilmeisesti Kävijällä ei kotia olekaan, vaan hän on jatkuvassa liikkeessä pitkin kairaa. Ainoa selitys on, kuten nimismies edellä toteaa, että hän on kamala, hirveä mies. Ja mikä voisi lapsen hahmon ympärille organisoituneessa maailmassa olla pahempaa kuin lapsen irrottaminen vanhemmistaan. Kävijä ryöstää lapsen, koska se on absoluuttisen pahuuden kuva. Romaani ei kuitenkaan anna Kiveliön kävijän voittaa. Myös tässä romaanissa on jotakin, joka on vahvempaa kuin paha tahto, ja se jokin on sama voima kuin Noidan kiroissakin.

Waltterin viimeisten elinpäivien aikana pappi vihkii hänet ja Eilan avioliittoon. Sitten Waltteri kuolee, ja Eila vannoo kostoa. Tällöin Waltteria hoitanut lääkäri muistuttaa Eilaa siitä, mikä on tärkeää:

- Nuori nainen! Teillä on lapsi, jonka vuoksi teidän kannattaa elää...

Eila herää kuin huumauksesta, näyttää kuin hänen kauniit silmänsä saisivat lämpöistä hehkua ja hän purskahtaa valittavaan, katkeraan itkuun...

Tuskaa...tuskaa...oi, sitä tuskaa... (T, 109-110)

Myös Tuskaa asettaa lapsen hahmon kertomuksen loppuun, ja tämä reproduktiivisen futurismin credo merkitsee heteroseksuaalisen kansakuntaisuuden voittoa sitä uhanneista voimista. Lapsi, ja tulevaisuuteen sitoutuminen lapsen takia, myös palauttaa Eilan paikalleen sukupolvien ketjuun, eikä hän ole enää peikkojen tapaan näiden kansakuntaisuuden kehysten ulkopuolella.

\section{Päätelmiä}

Olen tässä artikkelissa lukenut kolmea romaania, jotka kuuluvat 1910-luvun kirjallisuuden tiheään ruohonjuureen. Näitä romaaneja yhdistää ulkopuolisen hahmo, joka edustaa metonyymisesti villiä, luonnontilaista metsää tai erämaata, mutta on samalla myös queerin figuraatio ja konkretisoi sosiaaliseen järjestykseen rakenteellisesti kirjautuvaa mahdollisuutta sen omaan epäonnistumiseen. Tällä ulkopuolisen hahmolla on tässä luetuissa tarinoissa sama funktio, vaikka se saa kolmet eri kasvot: peikon, noidan ja oudon hiihtelijän. Hahmon tehtävä on tulla mitätöidyksi. Pelottava ulkopuolinen on se, jonka on väistettävä, jotta järjestys voi piirtyä esiin.

Aiempi tutkimus on osoittanut sekä pelottavan ulkopuolisen hahmon yhteydet goottilaiseen kauhuperinteeseen että sen, kuinka tällaisen hahmon kytkeytyminen villiin luontoon on goottilaisuuden erityinen skandinaavinen piirre. On myös osoitettu, kuinka tällaiset hahmot ovat osa pohjoismaisen kolonialismin historiaa ja kuinka kansantarinoissa peikot ja saamelaiset usein 
sekoittuivat toisiinsa ja saivat palvella toisina, joiden avulla pohjoinen kuvitteli itsensä länneksi. Tässä artikkelissa olen nostanut esiin sen, kuinka hahmoilla on myös funktio heteroseksuaalisen järjestyksen ulkopuolena.

Analysoimani viihteelliset romaanit ovat vakavalla asialla: ne kuvaavat ekspansiivista suomalaisuutta, joka 1900-luvun alussa kurottautui luonnontilaisiin erämetsiin metsänhoitajat etujoukkoinaan. Nämä romaanit eivät problematisoi järjestäytyneen kansakunnan levittäytymistä vaan esittävät sen paitsi luonnollisena myös vaihtoehdottomana. Vaihtoehtojen mahdollisuus kuitenkin varjostaa järjestystä, ja siksi tarvitaan niitä personoiva hahmo, joka kertomuksissa voitetaan tai vaiennetaan. Järjestyksen ulkopuolelle suljettavat hahmot edustavat yhtä aikaa luonnontilaista metsää ja ei-heteroseksuaalisen aluetta. On ikään kuin näiden molempien yhtäaikainen haltuunotto ja kieltäminen olisivat olleet suomalaisen kansakuntaisuuden artikuloitumisen ehto. Niin kuin historiallisesti ehkä olikin.

Kirjoittaja kiittää Katariina Kyrölää ja Karoliina Lummaata tekstiä työstäessään saamistaan hyödyllisistä kommenteista.

\section{Viitteet}

1 "[--] the death drive names what the queer, in the order of the social, is called forth to figure: the negativity opposed to every form of social viability." (Edelman 2004, 9.)

2 Sanna Karkulehto $(2007,111)$ on analysoinut peikkohahmoa Johanna Sinisalon romaanissa Ennen päivänlaskua ei voi, ja toteaa sen edustavan " kiellettyä, rajatilaista toiseutta ja outoutta, joita ei voi hallita rationaalisin keinoin". Myös tässä modernissa peikkovariantissa on uhkaavaa voimaa, joka on kesytettävä ja alistettava "rationaalisen valkoisen miehen valtaan" (mts. 112). Karkulehdon luennassa korostuu peikon seksuaalisuus: peikkoon sekä kohdistuu järjestäytyneen maailman fantasia alkukantaisesta, mutkattomasta seksuaalisuudesta että pelko siitä, että peikon edustama villiys pääsisi valloilleen ja järjestys tuhoutuisi (mts. 114).
Norjalainen gotiikan tutkija Johan Höglund on analysoinut pohjoismaisen nykyelokuvan peikkohahmoja ja näkee niiden edustavan saamelaisia: "Hahmon voi ymmärtää metaforisesti ekosysteemin goottilaiseksi representaatioksi, tai myöhäismodernin yhteiskunnan problemaattiseksi Toiseksi yleisessä mielessä. Täydentävä, ei suinkaan muut tulkinnat korvaava, tapa olisi lukea näitä hirviöitä suhteessa saamelaisalueiden kolonisaatioon." (Höglund 2017, 121, suom EH.) Höglund (2017, 117-121) analysoi nykyelokuvaa, mutta viittaa saamelaisten ja peikkojen pitkään sekoittumisen historiaan kansantarinoissa ja kirjallisuudessa ja kytkee tämän eurooppalaiseen kolonialismiin. Kuvitellessaan itsensä länneksi ja osaksi Eurooppaa pohjoinen tarvitsi oman goottilaisen toisensa, josta erottua.

Kiinnostavimpia viimeaikaisia peikkohahmojen tulkintoja on Katariina Kyrölän 
luenta Raja-elokuvasta. Kyrölä (2020, 1) esittää, että peikkohahmojen kautta käsitellään sellaisesta erilaisuutta, jota heteronormatiivinen Lapin kolonisoinut kulttuuri ei pysty käsittelemään. Kyrölän lähtökohdat ovat alkuperäiskansojen tutkimuksessa ja queer-teoriassa. Hän rakentaa peikkohahmojen luennalla tilaa käsitellä sitä, minkä kertomus kansakuntaisuudesta on vaimentanut; millainen on se maailma, jonka heteroseksuaalisuuteen kiinnittynyt kolonisoiva yhteisö sulkee ulkopuolelleen. Kyrölän lähtökohdat ovat queer-teoreetikko Eve Kosofsky Sedgwickin termistöllä reparatiiviset (mts. 21): hänen tavoitteenaan on analysoida queerin funktioita elokuvassa, ei niinkään dokumentoida sen kieltämistä ja siihen kohdistettua valtaa. Fokusoidessaan ulossulkemisen prosessiin oma hankkeeni on pikemminkin paranoidinen ja pyrkii ennen kaikkea paikantamaan alistamisen mekanismeja kirjallisuudesta, jossa ilmitasolla on kyse ihan muusta. Näen kuitenkin, etteivät reparatiivinen ja paranoidinen ole täysin toisensa poissulkevia lähtökohtia (ks. Callum \& Bradway 2019, 11). Jotain reparatiivista on jo siinä, jos pystyn osoittamaan, että nämä suositut viihteelliset luontokuvaukset käyttävät valtaa ja omalta osaltaan määrittelevät sitä, millaista suomalaisuus on. Jos ei väkivaltaisia mekanismeja tunnisteta, kuinka mikään reparatiivinen prosessi voisi edes alkaa?

\section{Aineisto}

Ahtela, H. (Einar Reuter) 1918. Pyhitysvaaran vanha asujain. Porvoo: WSOY.

Kataja, Väinö 1914. Noidan kirot. Kuvaus Lapin rajoilta. Hämeenlinna: Arvi A. Karisto Oy.

Kataja, Väinö 1907. Tuskaa. Kuvaus raukoilta rajoilta. Hämeenlinna: Arvi A. Karisto Oy.

Teuvo Puro (ohj.) 1927. Noidan kirot [elokuva]. https://elonet.finna.fi/Record/kavi.elonet_elokuva_117395 (11.10.2020).

\section{Kirjallisuus}

Berlant, Lauren 1997. The Queen of America Goes to Washington City. Essays on Sex and Citizenship.

Durham \& London: Duke University Press. https://doi.org/10.1515/9780822398639

Butler, Judith 1999. Gender Trouble. Feminism and the Subversion of Identity. $10^{\text {th }}$ Anniversary Edition. New York: Routledge.

Caserio, Robert L., Lee Edelman, J. Halberstam, José Esteban Muños \&Tim Dean 2006. The Antisocial Thesis in Queer Theory. PMLA 121(3), 819-828.

Edelman, Lee 2004. No Future. Queer Theory and the Death Drive. Durham \& London: Duke University Press. https://doi.org/10.1215/9780822385981

Harrison, Robert Pogue 1992. Forests: The Shadow of Civilization. Chicago: University of Chicago Press. https://doi.org/10.7208/chicago/9780226318059.001.0001

Hyttinen, Elsi 2014. Lustrous Flowers, Rotten Soil, and Someone to Make the Tea. The Queer in Early Finnish Working-Class Literature. SQS 8(1-2), 20-31.

Hyttinen, Elsi 2020. Miesten kanssa kulkevat miehet. Junapummikuvaukset, 1910-luku ja queer. Niin \& näin 27(2), 63-76. 
Höglund, Johan 2017. Revenge of the Trolls. Norwegian (Post) Colonial Cothic. Edda 104(2), 115-129. https://doi.org/10.18261/issn.1500-1989-2017-02-03

Karkama, Pertti 1998. Kaupunki kirjallisuudessa. Ongelmia ja näkökohtia. Teoksessa Paikkoja ja tiloja. Toim. Kaisa Kurikka. Turku: Turun yliopisto, Taiteiden tutkimuksen laitos, 13-37.

Karkulehto, Sanna 2007. Kaapista kaanoniin ja takaisin. Johanna Sinisalon, Pirkko Saision ja Helena Sinervon teosten queer-poliittisia luentoja. Oulu: Acta Universatis Ouluensis.

Kuisma, Markku 2006. Metsäteollisuuden maa. Suomi, metsät ja kansainvälinen järjestelmä 1620-1920. 2., korjattu painos. Helsinki: Suomalaisen Kirjallisuuden Seura.

Kyrölä, Katariina 2020. (Non-)sovereign erotics and queer desire in Cräns/Border (Ali Abbasi, 2018). Jätetty arvioitavaksi.

Leffler, Yvonne 2010. The Gothic Topography in Scandinavian Fiction. Teoksessa The Domination of Fear. Toim. Mikko Canini. Leiden: Brill, 43-51.

Lehtola, Veli-Pekka 1997. Rajamaan identiteetti. Lappilaisuuden rakentuminen 1920-ja 1930-luvun kirjallisuudessa. Helsinki: Suomalaisen Kirjallisuuden Seura.

Lehtola, Veli-Pekka 2019. Tunturin taika, korpien kirot. Vanhempi Lapin kirjallisuus 1901-1963. Rovaniemi: Väyläkirjat.

Lehtonen, Turo-Kimmo 2008. Aineellinen yhteisö. Helsinki: Tutkijaliitto.

McCallum, E. L. \& Tyler Bradway 2019. Introduction. Thinking sideways, or an Untoward Cenealogy of Queer Reading. Teoksessa After Queer Studies. Literature, Theory and Sexuality in the $27^{\text {st }}$ Century. Toim. Tyler Bradway \& E. L. McCallum. Cambridge: Cambridge University Press, 1-17. https://doi.org/10.1017/9781108627832.001

Paaskoski, Leena 2008. Herrana metsässä. Kansatieteellinen tutkimus metsänhoitajuudesta. Helsinki: Suomalaisen Kirjallisuuden Seura.

Sihvo, Hannes 2002. Monenlaisia metsäherroja. Teoksessa Hannes Sihvo: Vanhoilla urilla. Toim. Pekka Laaksonen \& Risto Turunen. Helsinki: Suomelaisen kirjallisuuden Seura.

Tieteen termipankki 21.01.2021: Nimitys:kiveliö. (Tarkka osoite: https://www.tieteentermipankki.fi/ wiki/Nimitys:kiveliö.)

Vadén, Tere 2010. Kaksijalkainen ympäristövallankumous. Tampere: Osuuskunta Rohkean reunaan.

Varis, Markku 2003: Ikävä erätön ilta. Suomalainen eräkirjallisuus. Helsinki: Suomalaisen Kirjallisuuden Seura. 